\title{
Rola organizacji pozarządowych w procesie integracji migrantów w Polsce. Przykład Łomży
}

\section{Streszczenie}

Celem artykułu jest przedstawienie roli organizacji pozarządowych w procesie integracji migrantów w Polsce. Egzemplifikacją teoretycznych rozważań jest analiza działań podejmowanych przez lokalną organizację pozarządową wobec migrantów w Łomży. Artykuł powstał na podstawie analizy desk research oraz badań terenowych, w których posłużono się techniką indywidualnych wywiadów pogłębionych prowadzonych z przedstawicielami władz lokalnych oraz organizacji pozarządowych. Analiza działań organizacji pozarządowej podejmowanych wobec migrantów w Łomży wykazała, że są to działania typowe dla tego typu podmiotów. Jednak fakt podejmowania działań w średniej wielkości mieście nadawał tej aktywności szczególną specyfikę, niespotykaną w dużych miastach.

Słowa kluczowe: integracja, migranci, uchodźcy, organizacja pozarządowa, Łomża Kody klasyfikacji JEL: H70, J60, O10

\footnotetext{
1 Szkoła Główna Handlowa w Warszawie, e-mail: jpopla@sgh.waw.pl, https://orcid.org/0000-00019588-3093

2 Szkoła Główna Handlowa w Warszawie, e-mail: justyna.gac@sgh.waw.pl, https://orcid.org/00000002-2050-5140
} 


\title{
The role of non-governmental organizations in the process of migrant integration in Poland: the example of Lomża
}

\begin{abstract}
The aim of the article is to present the role of non-governmental organizations (NGOs) in the process of migrant integration in Poland. To achieve this goal, a case study of Łomża and actions taken by a local NGO towards migrants are analyzed. The article was written on the basis of desk research and field research, in which the technique of individual indepth interviews conducted with the representatives of local authorities and non-governmental organizations was used. The analysis of the NGOs' activities towards the migrants in Łomża showed that these are typical activities taken by NGOs. However, the fact that these actions have taken place in a medium-sized city make it unique, different from the activities taking place in other large cities.
\end{abstract}

Keywords: integration, migrants, refugees, non-governmental organization, Łomża

JEL Classification Codes: H70, J60, O10

Polska jest krajem o bogatych tradycjach migracyjnych. Bardzo długo to Polacy wyjeżdżali za granicę w poszukiwaniu lepszego życia, jednak od $2016 \mathrm{r}$. liczba imigrantów w Polsce wzrosła i przekroczyła liczbę emigrantów (GUS, 2019). Na koniec lutego 2020 r. liczba cudzoziemców żyjących w Polsce była szacowana na ponad 2,2 mln osób, z czego 63\% stanowili Ukraińcy. Pozostali migranci w Polsce to obywatele Białorusi, Niemiec, Mołdawii, Rosji (w tym poszukujący międzynarodowej ochrony Czeczeni), Indii, Gruzji, Wietnamu, Turcji, Chin, a także Uzbekistanu, Kazachstanu i Nepalu (GUS, 2020).

Polska nie ma strategii integracji migrantów na poziomie narodowym, polityka publiczna wobec tej grupy osób jest rozproszona między zróżnicowane instytucje i akty prawne. Brak systemowych rozwiązań i regulacji rozwiązujących problemy migrantów powoduje, że rośnie rola zróżnicowanych organizacji społecznych: związków religijnych, sieci migranckich oraz organizacji pozarządowych. Rolą organizacji pozarządowych powinno być wspieranie władz w tworzeniu polityki publicznej wobec cudzoziemców. W praktyce jednak pełnią one kluczową rolę w działaniach pomocowych i integracyjnych wobec tej grupy mieszkańców (Dragan, 2017; Pawlak, 2018).

Wybór Łomży jako studium przypadku wynikał z kilku przesłanek. Ze względu na lokalizację ośrodka dla cudzoziemców w tym mieście w latach 2005-2010 mieszka tam do dziś kilkadziesiąt rodzin czeczeńskich, których integracja z lokalną społecznością nie zawsze przebiegała bez przeszkód. Po 2014 r. do Łomży zaczęło też przyjeżdżać 
coraz więcej Ukraińców. Duża grupa migrantów potrzebujących pomocy skłoniła Fundację Ocalenie do rozpoczęcia aktywności w tym mieście. Dodatkowym argumentem za wyborem Łomży do analizy była średnia wielkość tego miasta, co pozwoliło uchwycić tendencje trudne do zauważenia w większych ośrodkach miejskich.

Celem artykułu jest przedstawienie roli organizacji pozarządowych w procesie integracji migrantów w Polsce. Egzemplifikacją teoretycznych rozważań jest analiza działań podejmowanych przez lokalną organizację pozarządową wobec migrantów w Łomży. W artykule postawiono również pomocnicze pytania badawcze: Jakie są założenia polityki integracyjnej w Polsce i kto ją realizuje? Kim są migranci zamieszkujący Łomżę? Jakie działania podejmuje Fundacja Ocalenie? Jak pandemia COVID-19 wpłynęła na sytuację migrantów i zakres aktywności realizowanych przez Fundację Ocalenie?

Artykuł powstał na podstawie analizy literatury przedmiotu, danych statystycznych, prasy lokalnej oraz lokalnych dokumentów urzędowych (strategie rozwoju oraz program rewitalizacji). Uzupełnieniem analizy danych zastanych stała się jakościowa analiza indywidualnych wywiadów pogłębionych przeprowadzonych z przedstawicielami władz lokalnych (trzy wywiady) oraz organizacji pozarządowych (dwa wywiady). Wywiady prowadzono w marcu i kwietniu 2021 r. Dodatkowo w kwietniu 2021 r. przeprowadzono badanie ankietowe w Urzędzie Miasta Łomża.

\section{Założenia polityki integracyjnej w Polsce}

Wśród podstawowych dokumentów regulujących sytuację zróżnicowanych grup migrantów w Polsce należy wymienić: konwencję genewską z 1951 r. dotyczącą statusu uchodźców oraz protokół nowojorski z 1967 r. Polska ratyfikowała te dokumenty w 1991 r. Kolejny pakiet rozwiązań został wdrożony do polskiego porządku prawnego wraz z przyjmowaniem prawa wspólnotowego. Zgodnie z ramami współpracy Unii Europejskiej (UE) w zakresie procesu integracji migrantów sformułowanymi w 2004 r. „integracja jest dynamicznym dwutorowym procesem wzajemnego dostosowania się imigrantów i przyjmujących ich społeczeństw" (Rada Europejska, 2004 za: Komisja Europejska, 2011). Kraje członkowskie UE mają pewną swobodę w zakresie wdrażania dyrektyw UE dotyczących migracji do przepisów krajowych, co sprawia, że przyjęte w różnych państwach rozwiązania się różnią. Skutkuje to opóźnieniem rozpoczęcia procesu integracji, ponieważ migranci, w tym osoby ubiegające się o azyl i uchodźcy, przemieszczają się między państwami, poszukując tych z najkorzystniejszymi dla nich rozwiązaniami prawnymi (Europejski Trybunał Obrachunkowy, 2018: 3). 
W Polsce, podobnie jak w wielu innych państwach UE, polityka integracyjna stanowi element zróżnicowanych obszarów polityki publicznej. W konsekwencji pewne obszary funkcjonowania imigrantów reguluje ustawa z dnia 12 grudnia $2013 \mathrm{r}$. o cudzoziemcach oraz ustawa z dnia 13 czerwca 2003 r. o udzielaniu cudzoziemcom ochrony na terytorium Rzeczypospolitej Polskiej, ale regulacje większości aspektów integracji są rozproszone w wielu aktach prawnych, takich jak: ustawa o pomocy społecznej z 2004 r., ustawa o systemie edukacji z 1991 r., ustawa o usługach opieki zdrowotnej finansowanej ze środków publicznych z 2004 r. czy ustawa o systemie ubezpieczeń społecznych z 1998 r. (Rajca, 2015: 190-191). Takie rozproszenie rozwiązań występuje w wielu krajach UE i przekłada się na nieuwzględnianie w sposób systematyczny wszystkich grup migrantów i obszarów integracji (Europejski Trybunał Obrachunkowy, 2018: 4).

Integracja cudzoziemców przez dłuższy czas nie była przedmiotem zainteresowania rządzących, co wynikało z niewielkiej liczby imigrantów mieszkających na stałe w Polsce. Pierwsze działania integracyjne były prowadzone wobec osób oczekujących na nadanie statusu uchodźcy bądź innej formy ochrony, przebywających w ośrodkach dla cudzoziemców (Matusz-Protasiewicz, 2014: 14), a podstawowym instrumentem polityki integracyjnej państwa stały się Indywidualne Programy Integracji $(\mathrm{IPI})^{3}$ - to wokół nich tworzono dalsze rozwiązania (Wach, 2018: 355). W $2012 \mathrm{r}$. podjęto próbę stworzenia systemowego, zintegrowanego podejścia do integracji migrantów w Polsce. Rada Ministrów przyjęła wtedy dokument mający pełnić funkcję strategii, Politykę migracyjna Polski - stan obecny i postulowane działania. Jednak w październiku 2016 r., na wniosek ministra spraw wewnętrznych i administracji, dokument został unieważniony, a jako uzasadnienie tego działania wskazano kryzys migracyjny i zmianę sytuacji migracyjnej w Europie (Wach, 2018: 364). W późniejszym czasie prowadzono prace nad nową strategią, która jednak po upublicznieniu w 2019 r. spotkała się z zarzutami o nieprofesjonalne przygotowanie i ksenofobię (PAN, 2019). Do kwestii integracyjnych poruszonych w Polityce migracyjnej Polski - stan obecny i postulowane działania odnosił się dokument Polska polityka integracji cudzoziemców - założenia i wytyczne (Ministerstwo Pracy i Polityki Społecznej, 2013), który jednak nie został nigdy przyjęty przez Radę Ministrów i nie odegrał większej roli w tworzeniu polityki integracyjnej (Wach, 2018: 359-360). W $2021 \mathrm{r}$. został opublikowany projekt uchwały Rady Ministrów pt. Polityka migracyjna Polski

3 IPI prowadzone są przez Powiatowe Centra Pomocy Rodzinie (PCPR), mogą trwać nie dłużej niż 12 miesięcy i ustalane są w formie umowy między cudzoziemcem a PCPR. IPI obejmują: świadczenia pieniężne na utrzymanie i pokrycie wydatków związanych z nauką języka polskiego; opłacanie składki na ubezpieczenie zdrowotne, pracę socjalną; poradnictwo specjalistyczne (prawne, psychologiczne i rodzinne), udzielanie informacji i wsparcia w kontaktach $\mathrm{z}$ innymi instytucjami oraz inne działania wspierające proces integracji cudzoziemca. 
- kierunki działań 2021-2022. Polityka integracyjna stanowi jeden z sześciu obszarów tematycznych dokumentu, pozostałe to: legalna i nielegalna migracja, problem ochrony cudzoziemców, zagadnienie migracji Polaków oraz europejskiego wymiaru polityki migracyjnej.

\section{Integracja cudzoziemców - ramy organizacyjne}

Dla tworzenia polityki integracyjnej kluczowe znaczenie ma dostępność środków finansowych, które poprzez stymulowanie działań niejako wymuszały stworzenie założeń polityki. Wśród najważniejszych źródeł finansowania działań integracyjnych należy wskazać: Program Inicjatywy Wspólnotowej EQUAL i Europejskiego Funduszu na rzecz Uchodźców (EFU) ${ }^{4}$, Program ogólny „Solidarność i zarządzanie przepływami migracyjnymi” (SOLID), na który w kwestiach integracyjnych składał się Europejski Fundusz Uchodźczy (EFU) oraz Europejski Fundusz na rzecz Integracji Obywateli Państw Trzecich (EFI) (Wach, 2018: 347-348). Ograniczona dostępność środków finansowych z budżetu centralnego sprawiła, że organizacje pozarządowe pomagające cudzoziemcom zaczęły traktować fundusze europejskie jako podstawowe źródło finansowania. To uzależnienie spowodowało trudności $\mathrm{w}$ funkcjonowaniu wielu $\mathrm{z}$ tych podmiotów po 2015 r., kiedy programy EFI i EFU zostały zastąpione Funduszem Azylu, Migracji i Integracji (FAMI) oraz pojawiły się problemy z opóźnieniem rozpoczęcia programu i przeprowadzenia naborów projektów. W praktyce oznaczało to, że poza instytucjonalnym wsparciem migrantów przymusowych w ramach IPI oferta integracyjna organizacji pozarządowych została znacznie ograniczona (Wach, 2018: 362-364).

Politykę migracyjną w Polsce współrealizuje wiele instytucji, m.in. Ministerstwo Spraw Wewnętrznych i Administracji, Urząd ds. Cudzoziemców, Straż Graniczna, Wydziały Spraw Obywatelskich i Cudzoziemców w urzędach wojewódzkich. Z kolei Ministerstwo Rodziny, Pracy i Polityki Społecznej odpowiada za integrację cudzoziemców i rynek pracy, a edukacja dzieci i studentów międzynarodowych to obszar działania Ministerstwa Edukacji i Nauki. Polityka integracyjna nie należy do zadań własnych samorządów, a działania na poziomie lokalnym nie mają charakteru systemowego i opierają się na dobrej woli przedstawicieli samorządów oraz ich dobrowolnej współpracy z innymi podmiotami, zwłaszcza z organizacjami pozarządowymi. Poza największymi miastami jedynie nieliczne samorządy podejmują jakiekolwiek działania wykraczające poza ustawowe kompetencje (Rajca, 2015: 195).

\footnotetext{
4 Europejski Fundusz Uchodźczy zmienił nazwę na Europejski Fundusz na rzecz Uchodźców.
} 
Ważnym elementem polityki publicznej wobec migrantów, mającym wpływ na późniejszą ich integrację ze społecznością przyjmującą, są zasady lokalizacji ośrodków dla cudzoziemców. W Polsce są one umieszczane w miastach o zróżnicowanej wielkości oraz w byłych bazach wojskowych położonych na terenach leśnych. Lokalizacja ośrodka odbywa się bez konsultacji z lokalną społecznością, co niesie za sobą wielorakie - negatywne konsekwencje (Chrzanowska, Klaus, Kosowicz, 2011). Pominięcie opinii społeczności lokalnej w tak ważnej i kontrowersyjnej kwestii, brak wcześniejszej diagnozy nastrojów społecznych, brak akcji informacyjnej powodują niezadowolenie i napięcia społeczne. $\mathrm{Z}$ drugiej strony, lokalizacja ośrodka na terenach leśnych, w oddaleniu od ośrodków miejskich znacznie utrudnia migrantom kontakty ze społecznością przyjmującą.

Badania pokazują, że zakres działań integracyjnych i ich dotychczasowe efekty są niezadowalające. Realizowane obecnie programy i działania nie sprzyjają pełnej integracji migrantów. Największymi barierami w integracji uchodźców w Polsce są: zagrożenie bezdomnością, konieczność wynajmowania mieszkań w warunkach substandardowych, trudny dostęp do mieszkań komunalnych, niełatwa sytuacja na rynku pracy oraz nieznajomość języka polskiego (Łodziński, Ząbek, 2010: 244-247; NIK, 2015).

\section{Organizacje pozarządowe jako realizatorzy polityki integracyjnej}

Wielu autorów zwraca uwagę na kluczową rolę organizacji pozarządowych w procesie integracji migrantów. W odniesieniu do osób objętych ochroną międzynarodową podmioty te uzupełniają działania państwa, natomiast w wypadku innych kategorii cudzoziemców zastępują je (Slany, 2014: 8; Pawlak, Matusz-Protasiewicz, 2015: 11; Rajca, 2015: 194). Organizacje pozarządowe, świadcząc usługi obcokrajowcom, przyczyniają się do podnoszenia standardów działania instytucji publicznych, co ma wpływ na poprawę sytuacji wielu grup cudzoziemców (Pawlak, Matusz-Protasiewicz, 2015: 11).

W Polsce można wskazać kilkadziesiąt organizacji pozarządowych zajmujących się pomocą cudzoziemcom oraz nieformalnych grup osób podejmujących spontaniczne działania na rzecz imigrantów, często w odpowiedzi na konkretny problem (Dragan, 2017: 3). Specyfika działań podejmowanych przez organizacje pozarządowe wynika z potrzeb grupy cudzoziemców, którym świadczą one pomoc. W Polsce można wskazać trzy grupy migrantów: osoby objęte ochroną międzynarodową, obywateli państw trzecich i obywateli państw członkowskich Unii Europejskiej. Każda $\mathrm{z}$ tych grup ma inne uprawnienia w zakresie prawa pobytu i możliwości podjęcia 
pracy oraz zasad korzystania z instytucji pomocowych (Pawlak, Matusz-Protasiewicz, 2015: 13-16). Jako typowe aktywności organizacji pozarządowych można wskazać: pomoc informacyjną, doradczą, materialną, porady prawne oraz doradztwo zawodowe ułatwiające poznanie zasad funkcjonowania polskiego rynku pracy. Innym typem aktywności prowadzonej przez analizowane podmioty są działania o charakterze edukacyjnym, adresowane zarówno do imigrantów, jak i Polaków. Skierowane do imigrantów bezpłatne kursy języka polskiego czy działania ukierunkowane na wyrównywanie szans edukacyjnych dzieci mają wspierać ich integrację, z kolei działania edukacyjne w stosunku do Polaków mają na celu niwelowane stereotypów i uprzedzeń. Kolejną ważną płaszczyzną działań jest promocja wielokulturowości poprzez projekty ukierunkowane na integrację przedstawicieli różnych kultur. Inną kategorią aktywności są działania interwencyjne, a wśród nich: bezpośrednia pomoc wobec konkretnych osób czy grup, monitorowanie standardów w zakresie ochrony praw człowieka, szkolenia dla funkcjonariuszy organów państwowych oraz działania o charakterze rzeczniczym lub opiniodawczym (Slany, 2014: 13-26; Dragan, 2017: 6).

\section{Łomża i zamieszkujący ją migranci}

Przebieg integracji migrantów jest silnie uzależniony od społeczno-ekonomicznej charakterystyki miasta, w którym mieszkają i pracują. Łomża jest średniej wielkości miastem w województwie podlaskim. Miasto to liczyło w 2019 r. niemal 63 tys. mieszkańców, jednak należy podkreślić, że liczba ta systematycznie spadała - od 2011 r. do 2019 r. zanotowano spadek rzędu 3,5\%, co było m.in. wynikiem wyjazdów mieszkańców. Szczególnie dotkliwe z punktu widzenia rozwoju miasta były emigracje osób młodych, wykształconych, o wysokich kwalifikacjach. Zgodnie z prognozami demograficznymi Głównego Urzędu Statystycznego (2017) trend spadku liczby ludności Łomży będzie się utrzymywać. Rodowici mieszkańcy Łomży stanowią homogeniczną społeczność, jednolitą pod względem narodowościowym i religijnym. Jest to społeczność starzejąca się, w większości o konserwatywnych poglądach (PL_NGO_01; PL_LGOV_00).

Oprócz problemu depopulacji i starzenia się mieszkańców Łomża mierzy się z wieloma trudnościami ekonomicznymi, wśród których należy wskazać wysoką stopę bezrobocia, niedopasowanie strukturalne rynku pracy, niższe niż przeciętne w Polsce dochody. W 2019 r. stopa bezrobocia w Łomży wynosiła 7,5\%, podczas gdy wskaźnik ten dla Polski ogółem plasował się na poziomie 5,2\%. Bezrobocie dotykało szczególnie osób w wieku powyżej 50 lat, kobiet oraz osób z niepełnosprawnościami. Poważnym problemem było bezrobocie wśród osób w wieku poniżej 30 lat, 
w 2019 r. stanowili oni 38,4\% ogółu bezrobotnych w Łomży. Poważnym problemem była również skala bezrobocia długotrwałego, która w 2019 r. wynosiła 46,3\% (Powiatowy Urząd Pracy w Łomży, 2020). W 2019 roku Łomża mierzyła się również z problemem wysokiego niedopasowania strukturalnego na rynku pracy. Najbardziej poszukiwani przez pracodawców byli pracownicy z wykształceniem zasadniczym i średnim zawodowym, od kilku lat najwięcej ofert pracy pojawiało się w tych samych branżach i zawodach. W analizach obejmujących rok 2019 zwracano uwagę, że rynek pracy jest rynkiem pracownika, a pracodawcy nie tylko mają problemy ze znalezieniem fachowców, ale też jakichkolwiek rąk do pracy (Powiatowy Urząd Pracy w Łomży, 2020). Inną cechą charakterystyczną Łomży był relatywnie niski poziom wynagrodzeń. Przeciętne miesięczne wynagrodzenie brutto w relacji do średniej krajowej w latach 2002-2019 oscylowało między 79,4\% a 85,3\% (GUS, 2021). Niski poziom dochodów wpływał na wielkość popytu wewnętrznego, który z kolei miał swoje przełożenie na liczbę tworzonych miejsc pracy.

Depopulacja oraz problemy ekonomiczne sprawiały, że według różnych klasyfikacji Łomża była uznawana za miasto: kurczące się (Jaroszewska, Stryjakiewicz, 2014), tracące funkcje społeczno-gospodarcze (Śleszyński, 2016; Ministerstwo Inwestycji i Rozwoju, 2019), obniżającego się potencjału (Śleszyński, 2017), problemowe (Śleszyński, 2019) oraz za obszar strategicznej interwencji (Ministerstwo Inwestycji i Rozwoju, 2019). Problemy, z jakimi mierzyli się mieszkańcy miasta, nie sprzyjały ich integracji z migrantami.

Dokładne określenie liczby cudzoziemców w Łomży rodzi poważne trudności z powodu rozproszenia danych zbieranych przez różne instytucje publiczne (GUS, 2020). Wśród podmiotów agregujących dane należy wskazać Ministerstwo Spraw Wewnętrznych i Administracji (MSWiA), które gromadzi dane w związku z meldunkiem (rejestr PESEL), Zakład Ubezpieczeń Społecznych (ZUS) zbierający dane w związku z wykonywaną pracą. Osobne informacje zbiera Urząd Skarbowy, kolejny rejestr jest prowadzony przez Narodowy Fundusz Zdrowia (NFZ). Również Urząd ds. Cudzoziemców prowadzi własny rejestr (w związku z procedurą uchodźczą), inne dane zbiera Straż Graniczna w związku z przekroczeniem granicy. Szacunki dotyczące liczby cudzoziemców w Łomży są bardzo rozbieżne. Urząd miasta wskazał liczbę 218 - dane dotyczą liczby cudzoziemców spoza Unii Europejskiej zamieszkujących (na stałe bądź tymczasowo) Gminę/Miasto (ankieta, 2021), wg Wojewódzkiego Urzędu Pracy w Białymstoku było to w 2018 r. 2,5 tys. osób (Haberla, 2019). Jeden z rozmówców związany z władzami lokalnymi szacował ich liczbę na 1000 osób (PL_LGOV_00).

Pierwszą liczną grupą cudzoziemców w Łomży byli Czeczeni. Ich obecność wynikała z utworzenia w tym mieście ośrodka dla cudzoziemców w 2005 r. Osiedlono 
w nim przede wszystkim rodziny czeczeńskie. Po zamknięciu ośrodka w $2010 \mathrm{r}$. z zamieszkujących go w owym czasie ok. 200 osób (Portal Samorządowy, 2010) część wyjechała do innych miast lub za granicę (głównie do Niemiec lub Austrii), jednak wielu z nich zostało deportowanych, a w konsekwencji wróciło do Łomży. W 2021 r. w Łomży było wg relacji różnych rozmówców od 45 (PL_NGO_03) do ok. 60-70 rodzin czeczeńskich, a w każdej z nich średnio od trojga do sześciorga dzieci (PL_NGO_01), wg szacunków władz samorządowych było to ok. 300 osób (PL_LGOV_01). Jednak, mimo że liczba Czeczenów w Łomży jest względnie stała od 2010 r., to wg relacji rozmówcy współpracującego z nimi nie są to te same rodziny, występuje rotacja ludzi, rozmówca twierdził, że jedynie 10 rodzin mieszka na stałe w Łomży od 10 lat. (PL_NGO_01). Odmienna kultura i religia Czeczenów, w tym charakterystyczny ubiór kobiet, wyraźnie odróżniały tę grupę narodowościową od Polaków. Również niektóre zachowania Czeczenów, takie jak wieczorne spotkania dużych grup mężczyzn w przestrzeni publicznej, głośne rozmowy, uczestnictwo w grach hazardowych, czasem problemy z narkotykami, budziły w mieszkańcach niechęć, skojarzenia z czeczeńską mafią, a w efekcie poczucie zagrożenia i antypatię (PL_NGO_01, PL_NGO_03).

W 2010 r. zamknięto ośrodek dla cudzoziemców, a wydarzenie to było m.in. efektem działań posła Lecha Kołakowskiego należącego wówczas do partii Prawo i Sprawiedliwość (PiS), który zainicjował zbieranie podpisów pod petycją do Urzędu do Spraw Cudzoziemców. Poseł swoją aktywność uzasadniał wsłuchiwaniem się w prośby mieszkańców o podjęcie takich działań. Niektórzy zarzucali mu, że instrumentalnie wykorzystał uprzedzenia wobec migrantów do zdobycia poparcia społecznego dla swojej kandydatury na prezydenta Łomży, wywołując postawy ksenofobiczne. W sumie pod petycją o likwidację ośrodka dla cudzoziemców podpisało się ok. 770 osób (Klimowicz, 2010), czyli ok. 1,2\% mieszkańców.

Drugą ważną grupą cudzoziemców w Łomży są Ukraińcy. Zaczęli oni przyjeżdżać do Łomży po agresji Rosji na Ukrainę w 2014 r. Początkowo starali się w Polsce o ochronę międzynarodową, szybko jednak przekonali się, że taka forma pobytu jest niekorzystna ze względu na brak możliwości podjęcia zatrudnienia, a lepszym rozwiązaniem dla nich będzie migracja na podstawie zezwolenia na pracę. Większość Ukraińców przyjeżdżała w tym celu bez rodzin, traktując pobyt w Łomży jako tymczasowy, a nie miejsce stałego osiedlenia. W miejscu pracy zazwyczaj otrzymywali oni kwaterę i wyżywienie, zarobione pieniądze wysyłali do mieszkających wciąż na Ukrainie członków swoich rodzin. Stabilna sytuacja ekonomiczna w Polsce, a jednocześnie wieloletnia stagnacja gospodarcza na Ukrainie powodowały duże dysproporcje w zarobkach na korzyść Polski. Stąd dla Ukraińców praca nawet za najniższe stawki była opłacalna. Ta grupa migrantów nie różniła się od Polaków 
pod względem wyglądu zewnętrznego i kultury, stąd też społeczności łomżyńskiej łatwiej było zaakceptować ich obecność niż Czeczenów, byli też oni chętniej zatrudniani (PL_NGO_01; PL_LGOV_02).

\section{Działania integracyjne wobec cudzoziemców w Łomży}

Urząd miasta Łomża w prowadzonej polityce miejskiej nie poświęcał wiele uwagi migrantom. Świadczą o tym wyniki analizy dokumentów urzędowych, a także wypowiedzi przedstawiciela urzędu miasta. W wywiadzie rozmówca w sposób jednoznaczny potwierdził, że urząd miasta nie prowadzi osobnej polityki publicznej dedykowanej migrantom, gdyż grupa cudzoziemców zamieszkujących miasto jest na tyle mała, iż nie trzeba kierować w ich stronę specjalnych działań (PL_LGOV_03). Migrantów traktuje się podobnie jak inne grupy społeczne doświadczające problemów, czyli np. bezrobotnych i wykluczonych (PL_LGOV_02). Chętni mogą korzystać z pomocy socjalnej Miejskiego i Gminnego Ośrodka Pomocy Społecznej oraz Lokalnego Centrum Integracji. Jako ważny podmiot podejmujący działania na rzecz migrantów urzędnik wskazywał również szkoły (ankieta UM Łomża, 2021). Urzędnik wielokrotnie podkreślał, że działaniami dedykowanymi wyłącznie grupie migrantów zajmuje się Fundacja Ocalenie (PL_LGOV_03).

Fundację Ocalenie założono w 2000 r. w Warszawie. Jej aktywność w Łomży rozwijała się stopniowo, w miarę potrzeb i możliwości - początkowo ograniczała się do wizyt pracowników i wolontariuszy dojeżdżających z Warszawy, dopiero około 2006 r. powstała filia Fundacji w Łomży. Fundacja kierowała swoje działania zarówno do cudzoziemców przebywających w Polsce, jak i do społeczeństwa przyjmującego. Jej aktywności miały charakter długofalowej pomocy oraz doraźnego wsparcia migrantów, a także edukacyjny i integracyjny. Taki model funkcjonowania był spójny z koncepcją „dwukierunkowego procesu adaptacji imigrantów” promowanego przez Komisję Europejską wobec migrantów spoza UE (Rada Europejska, 2004). Założeniem tego podejścia jest zmiana wartości, norm i zachowań nie tylko przyjezdnych, ale też społeczeństwa przyjmującego (Łodziński, Grzymała-Kazłowska, 2011:20-21). Fundacja adresuje swoje działania do wszystkich cudzoziemców w Łomży, ale korzystają z niej głównie Czeczeni, co wynika z dużych różnic kulturowych między tą grupą a Polakami, a także z faktu, że Czeczeni przebywają w Polsce całymi rodzinami. 


\section{Działania pomocowe i edukacyjne kierowane do cudzoziemców}

Fundacja Ocalenie swoją działalność w Łomży rozpoczęła od otwarcia Centrum Pomocy Cudzoziemcom w 2006 r. W placówce tej cudzoziemcy mogli korzystać z pomocy psychologa, prawnika oraz mentora kulturowego, czyli osoby pochodzącej ze środowiska uchodźczego, która pomaga rozwiązywać codzienne problemy cudzoziemców. Szybko jednak okazało się, że pomoc jest również potrzebna dzieciom obcokrajowców, dla których zamieszkanie w nowym kraju nie było łatwym doświadczeniem. Z tego powodu Fundacja zaczęła prowadzić świetlicę, w której dzieci uczyły się języka polskiego, udzielano im pomocy w odrabianiu lekcji, a latem organizowano półkolonie dla dzieci cudzoziemskich i polskich (Ocalenie, 2021). Fundacja również współpracowała ze szkołami, w których uczyły się dzieci cudzoziemców, np. uczestnicząc w spotkaniach dla rodziców. Wszyscy rozmówcy zgodnie podkreślali, że to dzieci są pomostem między światem uchodźców a Polaków, kreują sytuacje, w których dorośli mają okazję się spotkać i poznać. Fundacja prowadziła również bezpłatne kursy języka polskiego, spotkania, podczas których edukowała cudzoziemców na temat zasad życia codziennego w Polsce, obowiązującego prawa, zwyczajów Polaków. Organizacja pomagała w szukaniu mieszkań na wynajem lub pracy. Pomoc ta była szczególnie ważna w obliczu braku znajomości języka polskiego wśród cudzoziemców, częstej niechęci i obaw Polaków przed wynajęciem mieszkania cudzoziemcom lub zatrudnieniu ich (PL_NGO_01). Odrębną formą pomocy było doraźne wsparcie materialne w postaci przekazywania środków czystości i higieny osobistej, ubrań, bonów do sklepów, a także paczek świątecznych. Fundacja pomagała również w zaspokojeniu nagłych i nietypowych potrzeb, np. w zorganizowaniu i transporcie potrzebnego wyposażenia do mieszkania (PL_NGO_01).

\section{Działania na rzecz edukacji społeczności przyjmującej, wzajemnego poznania i integracji}

Bardzo ważną częścią działań Fundacji była edukacja społeczności przyjmującej (PL_NGO_01). Działania te były szczególnie ważne w obliczu braku takiej aktywności ze strony władz publicznych, co byłoby w szczególności potrzebne i zasadne w przypadku lokalizowania w określonym miejscu ośrodka dla cudzoziemców. Fundacja Ocalenie w ramach swojej działalności organizowała szkolenia, warsztaty kulinarne i pogadanki w szkołach podstawowych i liceach, szkolenia dla instytucji publicznych 
(np. Straży Granicznej i dla Policji). Szkolenie dla Policji odbyło się na prośbę tej instytucji, według relacji rozmówcy było to kilka spotkań (PL_NGO_03). Osobną grupą działań Fundacji było organizowanie (lub współorganizowanie) tzw. dni integracyjnych, które miały za zadanie zapoznać społeczność przyjmującą z kulturą cudzoziemców. Wydarzenia te odbywały się zazwyczaj w miejskiej przestrzeni publicznej, wstęp był wolny dla wszystkich. Wydarzeniom towarzyszyły poczęstunki narodowymi potrawami. Nową formą wzajemnego poznania było organizowanie tzw. „żywej biblioteki”, która polegała na wytypowaniu migranta, któremu każdy z uczestników wydarzenia mógł zadać dowolne pytanie dotyczące życia codziennego, kultury i zwyczajów. W ostatnich latach Fundacja współorganizowała takie wydarzenia jak Dni Uchodźcy oraz Tydzień Wielokulturowości.

\section{Fundacja jako mediator w sytuacjach konfliktowych oraz współtwórca wzajemnych relacji}

Mimo działań edukacyjnych i integracyjnych, które podejmowała w Łomży Fundacja, zdarzały się w mieście sytuacje konfliktowe między Polakami a cudzoziemcami, akty agresji, takie jak pobicia, próby zerwania hidżabu czeczeńskim kobietom, a nawet dźgnięcia nożem. W takich sytuacjach Fundacja stawała się ważnym mediatorem, podejmowała działania, aby nie dopuszczać do eskalacji konfliktu, wzajemnej wrogości i długotrwałego zaburzenia stabilizacji życia codziennego. Działania organizacji nie przynosiłyby jednak efektów, gdyby nie ścisła wieloletnia współpraca z cudzoziemcami i wzajemne zaufanie. Wskazane konflikty dotyczyły przede wszystkim Czeczenów, a w ich rozwiązywaniu dużą rolę odgrywała starszyzna czeczeńska, która łagodziła napięcia i piętnowała członków własnej społeczności, jeśli popełniali czyny karalne (PL_NGO_01).

\section{Wpływ pandemii COVID-19 na działalność Fundacji Ocalenie i sytuację migrantów}

Skutki pandemii COVID-19, choć odczuwalne dla całego społeczeństwa, dla pewnych grup mniejszościowych, takich jak: osoby z niepełnosprawnościami, bezdomni czy migranci, były szczególnie uciążliwe. Pandemia zintensyfikowała wszystkie dotychczasowe problemy migrantów, a także przyczyniła się do pojawienia nowych. Problemy te miały zróżnicowane źródła, takie jak: ogólne załamanie na rynku pracy, ograniczenia wynikające z wprowadzonych obostrzeń sanitarnych, utrudnienia 
w dostępie do usług publicznych, ograniczenia w działalności placówek pomocowych i edukacyjnych, brak systemowych rozwiązań dotychczasowych problemów migrantów w postaci polityki migracyjnej na poziomie państwowym (PAN, 2021).

Załamanie się rynku pracy często oznaczało dla migrantów stratę dochodów, a tym samym brak środków do życia, utratę miejsca zamieszkania oraz brak dostępu do świadczeń socjalnych. W wyniku pandemii wydłużeniu uległa procedura postępowania legalizacyjnego, co uniemożliwiło np. legalne podjęcie pracy, wstrzymano również dostęp do procedury uchodźczej. Trudną sytuację migrantów dodatkowo pogarszało ich wykluczenie cyfrowe: brak dostępu do komputerów i Internetu, a w konsekwencji nieumiejętność ich obsługi. Ten problem dotyczył w istotnej mierze dzieci, co uniemożliwiało im edukację zdalną, a słaba znajomość języka polskiego dodatkowo utrudniała ich udział w nauczaniu. W konsekwencji pandemia zatrzymała proces integracji dzieci, nastąpił regres w ich znajomości języka polskiego. W łagodzeniu negatywnych skutków pandemii dla migrantów, zdaniem ekspertów Polskiej Akademii Nauk, kluczową rolę odgrywały organizacje pozarządowe (PAN, 2021). Badania jakościowe przeprowadzone na potrzeby napisania niniejszego artykułu w wysokim stopniu potwierdziły wyniki badań PAN (PL_NGO_01; PL_NGO_01).

Analiza działań integracyjnych i pomocowych podejmowanych wobec migrantów w Łomży potwierdza tezę o kluczowej roli organizacji pozarządowych w tym procesie. Pomoc świadczona przez te podmioty stała się jeszcze bardziej niezbędna w uwarunkowaniach pandemii. Należy jednak zauważyć, że chociaż aktywności Fundacji Ocalenie w Łomży były dość typowe dla takich organizacji, to ich lokalizacja w średnim mieście, w którym byli jedynym takim podmiotem, nadawała tym działaniom szczególną specyfikę. Migranci nawiązywali bliskie relacje z działaczami organizacji, jeden z rozmówców określał ich mianem swojej „drugiej rodziny”, „rodziny z wyboru”. Analizując skuteczność działań omawianej organizacji pozarządowej, nie sposób pominąć uwarunkowań, jakimi były charyzma i zaangażowanie lidera organizacji. Nie tylko zachęcił on wielu nowych wolontariuszy do stałej współpracy $\mathrm{z}$ organizacją, ale też nawiązując osobiste relacje z migrantami, zapraszając ich do udziału w uroczystościach rodzinnych, dawał innym mieszkańcom Łomży szansę na ich osobiste poznanie, jak i przykład, że relacje między Polakami a obcokrajowcami mogą być bliskie. Moi rozmówcy podkreślali, że osobiste poznanie konkretnych ludzi i bezpośrednie rozmowy są bardzo skutecznym narzędziem przełamywania stereotypów, obaw, poczucia obcości. Tworzenie sytuacji pozwalających na bezpośredni kontakt sprawia, że migrant przestaje być obcą kulturowo „jednostką", a zaczyna być po prostu „znajomym”, „sąsiadem”, „mieszkańcem Łomży”. 
Podsumowując, należy wskazać, że na początku trzeciej dekady XXI w. w trudnym procesie integracji migrantów ogromną rolę odgrywają organizacje pozarządowe. Wspieranie ich działalności i współpraca z nimi są więc kluczowe dla powodzenia tego procesu. Równie ważna jest obecność mądrych (PL_NGO_01) i dobrych osób (Chrzanowska, Klaus, Kosowicz, 2011), zaangażowanych w proces integracji, widzących w migrantach po prostu zwyczajnych ludzi. Jednak tylko trwałe rozwiązania systemowe mogą stworzyć uwarunkowania, aby proces integracji przebiegał harmonijnie we wszystkich miejscach, w których znajdą się migranci. Dalszy brak polityki migracyjnej na poziomie państwowym będzie prowadził do nieporozumień i problemów, gdyż trudne i złożone procesy nie mogą opierać się jedynie na charyzmie jednostek i działaniach średnio sformalizowanych organizacji.

W kontekście niniejszego artykułu pozytywnie należy ocenić rozwiązania zaproponowane w Polityce migracyjnej Polski - kierunki działań 2021-2022. W dokumencie zaproponowano m.in. usprawnienia w systemie legalizacji pobytu cudzoziemców oraz dostosowania rynku pracy, a także wiele postulatów mających na celu usprawnienie procesu integracji migrantów: zapewnienie cudzoziemcom dostępu do programów integracyjnych dostosowanych do ich potrzeb, wsparcie integracji poprzez system edukacji, $w$ tym działania skierowane do nauczycieli oraz pozostałej społeczności przyjmującej. W polityce migracyjnej podkreślono również potrzebę zapobiegania zjawisku przestrzennej segregacji, która może powodować wykluczenie społeczne, a także konieczność zwiększenia podaży mieszkań. Są to działania odpowiadające na wiele problemów migrantów zidentyfikowanych w trakcie badań terenowych w Łomży.

\section{Źródło finansowania}

Prezentowane badania stanowią część projektu badawczego pt. „Welcoming Spaces - Inwestowanie w »miejsca przyjazne migrantom « w Europie: rewitalizacja kurczących się obszarów poprzez przyjmowanie migrantów spoza UE”, który otrzymał finansowanie z programu badań i innowacji Unii Europejskiej Horyzont 2020 w ramach umowy nr 870952.

Artykuł odzwierciedla jedynie poglądy autorek i Komisja Europejska nie ponosi odpowiedzialności za jakiekolwiek wykorzystanie zawartych w nim informacji. 


\section{Bibliografia}

Chrzanowska, A., Klaus, W., Kosowicz, A. (2011). Polityka wyboru i lokalizacji ośrodków dla uchodźców. Analiza i rekomendacje. Warszawa: Stowarzyszenie Interwencji Prawnej.

Dragan, A. (2017). Organizacje pozarządowe zajmujace się pomoca dla uchodźców i migrantów. Warszawa: Kancelaria Senatu.

Europejski Trybunał Obrachunkowy (2018). Integracja migrantów spoza UE. Dokument analityczny, https://www.eca.europa.eu/Lists/ECADocuments/Briefing_paper_Integration_ migrants/Briefing_paper_Integration_migrants_PL.pdf (dostęp: 29.05.2021).

Fundacja Ocalenie (2021). Strona główna Fundacja Ocalenie, https://ocalenie.org.pl (dostęp: 26.05.2021).

GUS (Główny Urząd Statystyczny) (2017). Prognoza ludności gmin na lata 2017-2030. Warszawa, https://stat.gov.pl/obszary-tematyczne/ludnosc/prognoza-ludnosci/prognoza-ludnosci-gmin-na-lata-2017-2030-opracowanie-eksperymentalne,10,1.html (dostęp: 1.05.2021).

GUS (Główny Urząd Statystyczny) (2019). Rocznik Demograficzny. Warszawa, https://stat.gov. $\mathrm{pl}$ /obszary-tematyczne/roczniki-statystyczne/roczniki-statystyczne/rocznik-demograficzny-2019,3,13.html (dostęp: 25.05.2021).

GUS (Główny Urząd Statystyczny) (2020). Populacja cudzoziemców w Polsce w czasie COVID19. Warszawa: Główny Urząd Statystyczny, https://stat.gov.pl/statystyki-eksperymentalne/kapital-ludzki/populacja-cudzoziemcow-w-polsce-w-czasie-covid-19,12,1.html (dostęp: 25.05.2021).

GUS (Główny Urząd Statystyczny) (2021). Bank Danych Lokalnych, https://bdl.stat.gov.pl/ BDL/start (dostęp: 16.05.2021).

Haberla, M. (2019). Cudzoziemcy na podlaskim rynku pracy. Raport z badań. Białystok: Wojewódzki Urząd Pracy w Białymstoku, https://wupbialystok.praca.gov.pl/documents/ 102984/10969470/Cudzoziemcy\%20na\%20podlaskim\%20rynku\%20pracy/7862d0a7-b12b-4c42-a7ba-3b5d4283bdc0? t=1576581274924 (dostęp: 26.05.2021).

Jaroszewska, E., Stryjakiewicz, T. (2014). Kurczenie się miast w Polsce. W: Kurczenie się miast w Europie Środkowo-Wschodniej: 67-78, T. Stryjakiewicz (red.). Poznań: Bogucki Wydawnictwo Naukowe.

Klimowicz, J. (2010). Kosmici odlecą z Łomży. Gazeta Wyborcza, https://bialystok.wyborcza. pl/bialystok/7,35241,7731038, kosmici-odleca-z-lomzy.html (dostęp: 30.04.2021).

Komisja Europejska (2011). Komunikat Komisji do Parlamentu Europejskiego, Rady, Europejskiego Komitetu Ekonomiczno-Społecznego i Komitetu Regionów Europejski program integracji obywateli państw trzecich, SEK (2011) 957. Bruksela, https://eur-lex.europa.eu/ legal-content/PL/TXT/PDF/?uri=CELEX:52011DC0455\&from=PL (dostęp: 29.05.2021).

Łodziński, S., Grzymała-Kazłowska, A. (2011). Koncepcje, badania i praktyki integracji imigrantów. Doświadczenia polskie w europejskim kontekście. Studia Migracyjne - Przegląd Polonijny, 2(140): 11-39. 
Łodziński, S., Ząbek, M. (2010). Perspektywy integracji uchodźców w społeczeństwie polskim. Wyzwania normalnego życia. Ziemia obiecana czy przystanek w drodze?, Biuletyn RPO - Materiały, 70: 224-256.

Matusz-Protasiewicz, P. (2014). Wielopoziomowe zarzadzanie migracjami. Rola Europejskiego Funduszu na rzecz Integracji Obywateli Państw Trzecich w kształtowaniu polityki integracyjnej w Polsce. Wrocław: Uniwersytet Wrocławski.

Ministerstwo Inwestycji i Rozwoju (2019). Krajowa Strategia Rozwoju Regionalnego 2030, Załacznik 2. Imienna lista 139 miast średnich tracacych funkcje społeczno-gospodarcze, www.gov.pl/attachment/0179d436-5610-42e7-ab44-0337115e357c (dostęp: 26.05.2021).

Ministerstwo Pracy i Polityki Społecznej (2013). Polska polityka integracji cudzoziemców - założenia i wytyczne, zatwierdzony projekt z dnia 25.09.2013 r. Warszawa.

Ministerstwo Spraw Wewnętrznych i Administracji (2011), Polityka migracyjna Polski - stan obecny i postulowane działania. Warszawa.

NIK (Najwyższa Izba Kontroli) (2015). NIK o systemie pomocy społecznej dla uchodźców. Raport, https://www.nik.gov.pl/plik/id,10216, vp,12539.pdf (dostęp: 29.05.2021).

PAN (Polska Akademia Nauk) (2019). Stanowisko Komitetu Badań nad Migracjami PAN w sprawie dokumentu „Polityka migracyjna Polski”, https://kbnm.pan.pl/images/Stanowisko_KBnM_Polska_polityka_migracyjna_03072019.pdf (dostęp: 29.05.2021).

PAN (Polska Akademia Nauk) (2021). Stanowisko 15. zespołu ds. COVID-19 przy prezesie PAN: Wpływ pandemii na wybrane grupy mniejszościowe w Polsce, https://informacje. pan.pl/index.php/informacje/materialy-dla-prasy/3314-stanowisko-15-zespolu-ds-covid-19-przy-prezesie-pan-wplyw-pandemii-na-wybrane-grupy-mniejszosciowe-w-polsce (dostęp: 25.05.2021).

Pawlak, M. (2018). Polityki publiczne wobec migracji. W: Nauki o polityce publicznej: Monografia dyscypliny: 288-311, J. Kwaśniewski (red.). Warszawa: Instytut Profilaktyki Społecznej i Resocjalizacji UW.

Pawlak, M., Matusz-Protasiewicz, P. (2015). Organizacje pozarządowe wobec cudzoziemców w Polsce. Od pomocy doraźnej do upowszechniania europejskiej ramy polityki integracji. Trzeci Sektor, 35(2): 11-21.

Portal Samorządowy (2010). Ośrodek dla uchodźców pozostanie w Łomży, https://www.portalsamorzadowy.pl/polityka-i-spoleczenstwo/osrodek-dla-uchodzcow-pozostanie-w-lomzy,11626.html (dostęp: 30.04.2021).

Powiatowy Urząd Pracy w Łomży (2020). Monitoring zawodów deficytowych i nadwyżkowych w powiecie miasto Łomża w 2019 roku, Łomża, https://lomza.praca.gov.pl/documents/ 1938845/13027219/Monitoring\%20zawod\%C3\%B3w\%20deficytowych\%20i\%20nadwy\%C5\%BCkowych\%20 w\%20powiecie\%20\%C5\%81om\%C5\%BCy\%C5\%84skim\%20 w\%202019\%20roku.pdf/95fb2cab-a9dd-4a36-b93c-64966a8fa9b7? t=1596006110753 (dostęp: 29.05.2021).

Rada Europejska (2004). Wspólne podstawowe zasady integracji imigrantów dla wzmocnienia spójnych europejskich ram integracji obywateli państw trzecich (Common Basic Principles for Immigrant Integration Policy in the EU). Dokument 14615/04 z dnia 19.11.2004, https:// ec.europa.eu/migrant-integration/librarydoc/common-basic-principles-for-immigrant-integration-policy-in-the-eu (dostęp: 6.09.21). 
Rada Ministrów (2021). Projekt uchwały Polityka migracyjna Polski - kierunki działań 2021-2022, https://www.gov.pl/web/mswia/projekt-uchwaly-rady-ministrow-w-sprawie-przyjecia-dokumentu-polityka-migracyjna-polski--kierunki-dzialan-2021-2022-id179 (dostęp: 31.08.2021).

Rajca, L. (2015). Integracja imigrantów w Polsce w dobie kryzysu migracyjno-uchodźczego. Chorzowskie Studia Polityczne, 10: 183-202.

Śleszyński, P. (2016). Delimitacja miast średnich tracacych funkcje społeczno-gospodarcze. Warszawa: Instytut Geografii i Przestrzennego Zagospodarowania PAN.

Śleszyński, P. (2017). Wyznaczenie i typologia miast średnich tracących funkcje społeczno-gospodarcze. Przegląd Geograficzny, 89(4): 565-593.

Śleszyński, P. (2019). Aktualizacja delimitacji miast średnich tracących funkcje społeczno-gospodarcze (powiększających dystans rozwojowy). Warszawa: Instytut Geografii i Przestrzennego Zagospodarowania PAN.

Ślusarczyk, M., Nikielska-Sekuła, K., Strzemecka, S., Slany, K. (2014). Wsparcie, pomoc, inicjatywa. Przewodnik po organizacjach pozarządowych imigrantów i dla imigrantów. Raport dla Sekcji Badań nad Współczesnymi Migracjami Komitetu Badań nad Migracjami PAN. Kraków: Instytut Socjologii Uniwersytetu Jagiellońskiego.

Wach, D. (2018). Ewolucja polskiej polityki integracji cudzoziemców po 1989 roku. W: Polityka migracyjna w obliczu współczesnych wyzwań. Teoria i praktyka: 347-367, H. Chałupczak, M. Lesińska, E. Pogorzała, T. Browarek (red.). Lublin: Wydawnictwo Uniwersytetu Marii Curie-Skłodowskiej.

Unless stated otherwise, all the materials are available under 